\title{
The governance features of social enterprise and social network activities of collective food buying groups
}

Tom Dedeurwaerdere ${ }^{(1) *}$, Olivier De Schutter ${ }^{(1)}$, Marek Hudon ${ }^{(3)}$, Erik Mathijs ${ }^{(2)}$, Bernd Annaert ${ }^{(2)}$, Tessa Avermaete $^{(2)}$, Thomas Bleeck ${ }^{(1)}$, Charlotte de Callatä̈ ${ }^{(1)}$, Pepijn De Snijder ${ }^{(1)}$, Paula Fernández-Wulff ${ }^{(1)}$, Hélène Joachaim ${ }^{(3)}$, Jose-Luis Vivero ${ }^{(1)}$

(1) Université catholique de Louvain

(2) KULeuven,

(3) Université Libre de Bruxelles

$(*)$ corresponding author: tom.dedeurwaerdere@uclouvain.be

This is a draft (pre-print) version of an article which appeared in 'Ecological Economics'.

Check the following website for the final, published version:

https://doi.org/10.1016/j.ecolecon.2017.04.018

\section{Research highlights}

- Provides a comparative analysis of 104 collective food buying groups (CFBGs) in Belgium

- Shows the importance of two distinct governance components, respectively related to social networking and social enterprise activities

- Decentralized modes of coordination with other organisations (decentralized information sharing, decentralized sharing of resources and joint activities) play a key role in the governance of the social network activities

- CFBGs oriented towards the transformation of farming systems have a higher focus on the social network activities

- This result is valid, independently of the choice of the organizational form (such as farm-consumer cooperatives, consumer associations, internet based social enterprises)

\begin{abstract}
Collective food buying groups, such as community supported agriculture or self-organized citizen groups for delivery of food baskets, have emerged throughout the world as an important niche innovation for promoting more sustainable agri-food systems. These initiatives seek to bring about societal change. They do so, however, not through protest or interest-based lobbying, but by organizing a protected space for learning and experimentation with lifestyle changes for sustainable food consumption and production practices. In particular, they aim to promote social learning on a broad set of sustainability values, beyond a focus on "fresh and healthy food" only, which characterizes many of the individual consumer oriented local food chain initiatives. This paper analyses the governance features of such local food buying groups by comparing 104 groups in five cities in Belgium. We find that the social networking activities of these groups, as compared to the social enterprise activities, have led to establish specific governance mechanisms. Whereas the main focus of the social enterprise activities is the organisation of the food provisioning logistics, the focus of the social network activities is the sharing of resources with other sustainable food initiatives, dissemination of information and broader discussion on sustainability issues.
\end{abstract}

Key-words: Local food networks; community supported agriculture; social enterprises; social networks; sustainability transitions 


\section{Table}

1 Citizen-based learning in transitions towards sustainable agri-food systems ................................ 3

2 The contribution of collective food buying groups to learning on lifestyle changes ...................... 5

3 Combining social enterprise and social network activities in collective food buying groups ......... 6

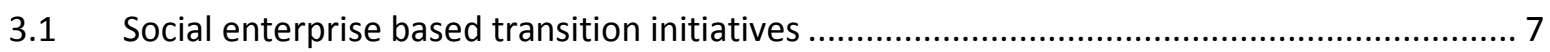

3.2 The role of social networking for promoting civic learning ............................................... 9

4 Data collection, empirical model and methodology ................................................................... 10

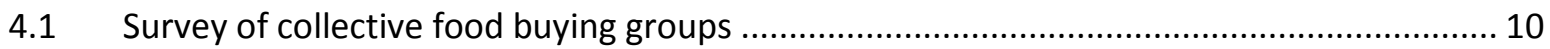

4.2 Specification of the hypothesis and empirical model ....................................................... 11

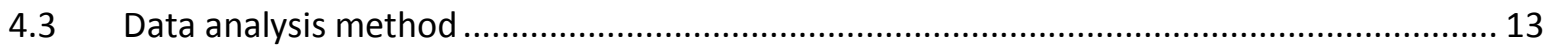

5 Governing social networking in collective food buying groups .................................................. 14

5.1 Common features of the collective food buying groups ..................................................... 14

5.2 Governance features related to the social enterprise service activities and the social

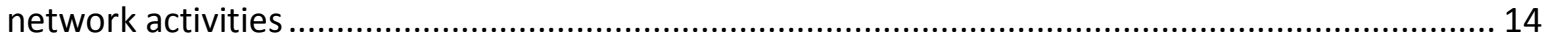

6 Consequences for the role of decentralized social networking in agri-food transitions .............. 19

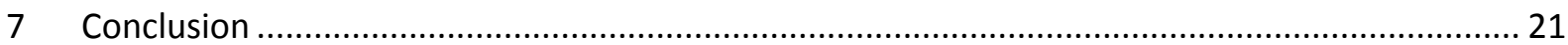

Annex 1. Definition of the variables and descriptive statistics ......................................................... 27

Annex 2: Correlation matrix amongst the independent variables...................................................... 30 


\section{Citizen-based learning in transitions towards sustainable agri-food systems}

Together, the provision of agricultural inputs, and the production, packaging, processing, transport, and distribution of food, represent $19-29 \%$ of greenhouse gas emissions worldwide (Vermeulen et al., 2012); and they exert an important pressure on natural resources, water, nitrogen and phosphate, and arable land in particular. Reforming food systems towards greater sustainability is therefore essential for a transition towards a low-carbon and resource-efficient society (De Schutter, 2014). Increasingly broad segments of society demand such a switch, and appear to search for alternatives. As a result, the consensus on increased production as the key objective of agri-food policies, which emerged after the Second World War, has lost much of its appeal and is partly replaced by a variety of new approaches and value orientations. Economic efficiency and technological rationalisation remain important, but new concerns are emerging about nutritional quality, food safety, environmental impacts, resource efficiency and social equity. These concerns now appear as equally important organising principles around which product innovation and new consumption practices evolve (Mathijs et al., 2006; Spaargaren et al., 2012).

The involvement of citizens and consumers in sustainable local and regional food networks has emerged over the last decades as one of the tools for promoting civic learning on change in production and consumption practices. The contribution of local food networks to bringing about a shift to more sustainable agri-food systems is however a matter of intense debate. Indeed, trade-offs may be involved in such initiatives between the various sustainability features. For instance, a large-scale study by scientific experts, regional stakeholders and practitioners of local food networks within five metropolitan areas in Europe shows that, whereas short and regional food chains generally perform better than the conventional global long food chains as regards environmental sustainability, this is not necessarily true for all type of short and regional food chains: rather than rewarding producers with the most sustainable agronomic practices and thus providing benefits to the society as a whole, some short and regional food chains in fact respond to the preferences of individual consumers for "fresh and healthy" food linked to local food cultures (Foodmetres, 2014).

Within the wealth of the citizen-led initiatives on transitions to more sustainable agri-food systems, collective food buying groups occupy a very specific space. Collective food buying groups are based on partnerships between consumer groups that build a direct partnership with one or a set of farmers for the delivery of food baskets on a regular basis. Early initiatives of Collective Food Buying groups already developed in Japan, Germany and Switzerland in the 1960s (Schlicht et al., 2012), with women taking the lead in Japan to found Teikeis, one of the first forms of family-farmer partnerships (David-Leroy and Girou, 2009; Schwartz, 2011). After the emergence of these early social innovations, consumer groups / producers partnerships for sustainable agri-food production have developed also in other countries. By January 2017, more than 700 community-supported agriculture schemes (so-called "CSAs") are registered on the directory of the US Department of Agriculture (USDA, 2017). In France, currently, over 1500 farm-consumer associations have been set up by consumers and citizens for the 
support to peasant agriculture in France (AMAP: Association pour le Maintien d'une Agriculture Paysanne) (Schlicht et al., 2012).

These collective food buying groups share some features with other, more individual consumer oriented, initiatives for reforming the food systems. Examples of such individual consumer oriented initiatives are the introduction of local food stalls in major supermarket chains or online ordering systems of food baskets with a network of deposit hubs. In a similar vein as the collective food buying groups, these initiatives aim at building a more direct consumer-producer logistic chains based on the local food economy. However, the collective food buying groups clearly aim to go beyond merely broadening the range of choices for the responsible individual consumer around the theme of "fresh and healthy foods" (cf. also, Forno et al., 2015). Indeed, these groups also invest time and resources in implementing social experimentation broader social and ecological sustainability values, such as solidarity with small-holder farmers, less production of packaging waste and the decrease of food miles for sustainable farm products.

In spite of this diverse landscape, and the scientific uncertainty with regards to the best available development path for ecologically and socially sustainable agri-food systems, the collective food buying groups provide a social innovation that has proven to be attractive to a growing number of consumers. However, although such small niche initiatives do not have the economic weight nor the power to bring about the needed transformation of the agri-food systems, they still play an important role through at least two channels. First, though they may not have the potential of bringing about system-wide transformation in and of themselves, such niche innovations can add pressure on mainstream regime players to change. The literature on transition management suggests that coalitions between niche innovations pushing for more radical lifestyle changes and large-scale regime players that are willing to make modest but real changes are needed to reach the necessary threshold for system transformation (Rotmans and Horsten, 2012; Loorbach et al., 2016). Second, these niche innovations promote a more active involvement of citizens in learning on potential options for agrifood transitions. Such an active involvement can contribute in turn to broadening the critical debate and the social construction of common meanings around the possible pathways for transition amongst diverse social groups.

To contribute to a better understanding of these features, this paper focuses on a sample of collective food buying groups in Belgium which is representative of the broad variety of organisational types of these groups (such as farm-consumer cooperatives, consumer associations, internet based social enterprises). Our hypothesis is that the successful promotion of civic learning on new modes of food provisioning and consumption in these groups relies on a combination of two main types of activities: first, the organisation of a set of economic service activities, based on both voluntary and paid labour, around direct food provisioning from small-holder farmers and, second, the decentralized networking with other sustainability transition initiatives - especially through the sharing of resources with other food buying groups and the dissemination of information on activities and broader discussion on sustainability issues with other food transition organisations. By testing this hypothesis for this specific niche innovation, our goal is to contribute to the scholarly literature on the role of the governance of niche initiatives in sustainability transitions.

The paper is structured as follows. The second section discusses the social movement features of the food buying groups and their role in civic learning on sustainability transitions. The third section 
elaborates on the two main challenges for these collective food buying groups, which is the organisation of the food provisioning logistics through citizen involvement in an economically sustainable manner and the governance of the decentralized social networks in support of the social movement features. The fourth and fifth sections present the analysis of the semi-structured questionnaire and discuss the results from the comparative analysis of a representative set of 104 collective food buying groups in Belgium. The sixth section provides an overall discussion and highlights some governance recommendations that result from the analysis.

\section{The contribution of collective food buying groups to learning on lifestyle changes}

While awareness about the global sustainability crisis is growing, there remains a considerable gap between that awareness and individual lifestyle choices (UNEP, 2011). There also remains a troubling disconnect between the emerging transition initiatives, which broaden the range of alternatives individuals may choose from, and the lifestyle choices of the majority of the population.

To identify the key areas where consumers' choice can have the highest impact on agri-food transitions, researchers conducted a life cycle analysis of the key ingredients of typical food portions in Finland (Virtanen et al., 2011). The results indicate that rewarding certain agronomic choices linked to sustainable agriculture production methods and reducing meat consumption have the highest impact. The choice of agricultural production method has a major impact on the reduction of greenhouse gases responsible for climate change. This holds even for imported products, as this impact outweighs by far the role of international transport. Choosing products that are grown with a low use of external inputs has therefore a key role to play in reducing the ecological footprint of food consumption, whether the foods are locally sourced or have travelled long distances. Similarly, the increase of the share of vegetables in the diet, as compared to meat, especially of vegetables that grow well in the local climate, can significantly reduce the ecological footprint of food consumption (see also D'Silva and Webster, 2010; and Lymbery, 2014).

Some scholars have analysed the role of collective food buying groups in the change in farmers' modes of production and in the dietary habits of consumers. For instance, field work on collective food buying groups has shown that these groups play a key role in supporting local producers to move from conventional high-input production systems to low-input and/or organic farming systems. Further, Bougherara et al. (2009) analyse responses of a sample of 264 French households about their participation to Community Supported Agriculture (CSA) projects and find out that environmental considerations play a major role in explaining CSA participation. As regards change in dietary habits, case studies show that participation in community gardens and school gardens has a clear positive effect on greater fruit and vegetable intake (Alaimo et al., 2008; Litt et al., 2011; Allen et al., 2016). Moreover, sourcing food locally increases the freshness of the food consumed and improves its nutritional content.

As can be seen from the studies collective food buying groups, the benefits expected from consumerproducer partnerships however are not purely environmental or nutritional. While the impacts vary strongly from one type of initiative to another, other societal benefits that play a role are increased transparency of decisions within the food chain, viability of food culture, social cohesion, public health or reduction of packaging and food loss (Marsden and Smith, 2005). For instance, Bloemmen et al. 
(2015) analyse some self-harvested CSA projects in Belgium and find that most consumer participants were non-profit seeking, and favoured quality small-scale production. Moreover, consumers were attracted by community participation, conviviality and a sense of responsibility towards nature. Further, most comparative studies underline also the social benefits of the local food networks, such as the contribution to social cohesion in cities and the promotion of food traditions and culture (Schlicht et al., 2012; Foodmeters, 2014).

Even though the focus varies from one group to another, this pursuit of such a broader set of values requires a specific form of collective action, which is absent from the pure "fresh and healthy" local food initiatives. This implies additional constraints to the participants, such as yearly contracts with the farmer in some cases, or participation to meetings or organizational tasks in other cases. Further, in some groups, search for new sustainable product providers is facilitated by initiatives of group members, which collectively discuss on the appropriate choices with the other members, assess the ecological and social aspects of the various provisioning options and test the new products within the group. Considering the time invested and the economic inefficiencies related to the collective processes, the motivations reaching beyond "fresh and healthy" have to be sufficiently strong, not least since accessible and attractive cost-competitive alternatives for locally sourced food products emerge, such as the on-line ordering of food baskets or the local food stalls in supermarkets.

The local food buying groups therefore face a dual challenge: organizing the logistics for provisioning of food from sustainable farming and investing time and energy in the broader civic learning on lifestyle changes for supporting more sustainable agri-food systems. As a consequence, the collective food buying groups may be seen as hybrids, combining two overlapping components. The first is the social enterprise component (in some case fully non-profit, in some cases limited profit, cf. table 1. below), whose core activity consist in organizing the food provisioning logistics. The second is the social network component, related to the dissemination and collective learning around the experimentation with concrete pathways for lifestyle changes. Although these components overlap, in some local food buying groups activities within one of these two components have been organised separately, such as for instance the participatory guarantee system created for organizing the food logistics in Voedselteams Vzw (an umbrella of collective food buying groups in the Dutch-speaking part of Belgium). In general however, we refer in this paper to the "components" as two clusters of activities related respectively to (i) the sustainable and local food logistics in the collective food buying group on the one hand and to (ii) the broader civil learning and experimentation in a network with other organisations on the other hand.

\section{Combining social enterprise and social network activities in collective food buying groups}

The direct consumer-producer partnerships established through the collective food buying groups (CFBGs) organise a broad variety of activities. Some are of a not-for-profit nature (such as the voluntary contribution by the members to collection, distribution and sale), other activities instead lead to monetary gain (such as the activities of the producers and small transport enterprises). This combination of not-for-profit and for-profit activities can play a crucial role in ensuring the economic viability of the local and regional food networks (Dunning, 2013; Pinchot, 2014). By participating in 
local and regional food networks, farmers can receive shares of the final price paid by the consumer that are 70 to 80 percent higher than what the farmers would receive if they were selling through large retailers (King et al., 2011). Similarly, the consumers participating in the system may make significant savings, as shown by studies of organic produce distributed through local food buying groups (Cooley and Lass, 1998; Brumauld et Bolazzi, 2014).

By combining not-for profit and for-profit activities, and given the objective of contributing to broader societal benefits, the CFBGs share some important features with social enterprises (Borzaga et al., 2001). Nevertheless, in spite of these important economic features, many scholars argue that it would be mistaken to consider these consumer-producer partnerships only through the lens of the social enterprise aspect (Connelly et al., 2011; Foodmeters, 2014). Indeed, as seen above, many alternative food networks see themselves as part of a broader social movement that strives to promote a transition towards low-input, low-carbon agri-food systems. They do so, however, not merely through protest or interest-based lobbying, but by networking with other initiatives that promote sustainable alternatives to the mainstream food production and consumption pathways. Further, as also highlighted through our survey results, they also link to non-food initiatives, through mutual recognition and joint projects, for instance related to social integration, fair trade and sustainable mobility.

In this section, we review some of the literature on these two activities of the CFBGs - the social enterprise activities and the social network activities - and we discuss the challenges they face.

\subsection{Social enterprise based transition initiatives}

Scholars of socio-ecological transition have shown a growing interest in the contributions of social enterprises to sustainable development (Seyfang and Smith, 2007; Johanisova et al., 2013). In this context, they consider social enterprises not simply as a tool to alleviate social problems generated by market imperfections, but also as an organisational model that can support social innovations for transition to more sustainable consumption and production practices. More specifically, by accessing a series of non-market resources (such as unpaid labour, affordable small loans, lower-than-market rent for premises, various sharing arrangements for the use of resources), social enterprises can provide an effective survival strategy for transition initiatives, which would otherwise not be able to survive in increasingly competitive markets focused on satisfying the short term expectations of shareholders.

In a broad sense, social enterprises are organisations involved in market activities but with a primacy of the societal mission, which can be related to of social, cultural and/or environmental purposes (Chell, 2007). The primacy of the societal aim is generally reflected in constraints on the distribution of profits (from a total non-distribution constraint to certain limitations on the distribution of profit). These constraints are seen as a means of preventing pure profit-maximizing behaviours (Defourny and Nyssens, 2010). The total non-profit constraint is usually defined by a non-distribution constraint of profits to members, investors, managers or other types of stakeholders (Anheier, 2005, p. 40), while in the case of a limited distribution constraint, members receive limited compensation within a clearly legally specified framework (cf. the examples of several new legal forms for social enterprises in European countries (UK, Italy, Belgium, France, Portugal, Poland, Hungary, Spain or Greece) (Fici, 2015)). However, some social enterprises adopt traditional forms of commercial companies without any type of constraints looking for "double or triple bottom line" balancing social impact and the 
remuneration of shareholders. Among schools of thought of social enterprise, some of them, especially those rooted in the cooperative tradition, pay particular attention to democratic ownership structure. The latter is often implemented through a one-member-one-vote rule (rather than one-share-onevote). In other cases, this constraint implies at least that the voting rights in the governing body with the ultimate decision-making power are not distributed according to capital shares alone (Defourny and Nyssens, 2010; Nyssens and Defourny, 2016).

CFBGs illustrate the emerging role of these various types of social enterprises in the transition to more sustainable consumption and productions patterns. Although they remain small niche innovations in many countries, they sometimes evolve into large and established organisations, as highlighted in the introduction. As shown in table 1, CFBGs partnerships rely on a variety of organisational forms, which are social cooperatives, social interest enterprises or voluntary associations. Because their objectives are primarily social or ecological in nature, none of them have adopted a for-profit legal status (which would be the case for instance in purely economic cooperatives). While some are organized as legal non-profit associations, others have benefited from the specific legal status created under Belgian or French law for limited profit sharing organisations.

Table 1. Type of social enterprises covered in the study of the CFBGs operating in Belgium. "Nondistribution constraint" refers to non-distribution of assets or income to individuals as owners or managers except for fair compensation for services rendered (Anheier, 2005, p. 40). "Limited distribution constraint" allows for the distribution of profits, but under strict conditions defined in the regulatory framework.

\begin{tabular}{|c|c|c|c|c|}
\hline & Legal form & $\begin{array}{l}\text { Cases analysed in this } \\
\text { paper (details of } \\
\text { acronyms in table } 2 \\
\text { below) }\end{array}$ & Paid work & Voluntary work \\
\hline $\begin{array}{l}\text { Total non- } \\
\text { distribution } \\
\text { constraint }\end{array}$ & Association & $\begin{array}{l}\text { GAC/AMAP/GASAP } \\
\text { Voedselteams }\end{array}$ & $\begin{array}{l}\text { To the farmer } \\
\text { (produced food) }\end{array}$ & $\begin{array}{l}\text { Accounting } \\
\text { Product search } \\
\text { Organisation of } \\
\text { meetings }\end{array}$ \\
\hline \multirow[t]{2}{*}{$\begin{array}{l}\text { Limited distribution } \\
\text { constraint (under } \\
\text { Belgian and French } \\
\text { law) }\end{array}$} & $\begin{array}{l}\text { Social interest } \\
\text { solidarity enterprise } \\
\text { (ESUS: France, } \\
\text { Decree of } 5 \text { August } \\
\text { 2015) }\end{array}$ & La Ruche qui dit Oui & $\begin{array}{l}\text { To the farmer } \\
\text { (produced food) } \\
\text { To the software } \\
\text { designers ( } 8,35 \% \text { of } \\
\text { the sales) } \\
\text { To the person } \\
\text { making selling space } \\
\text { available ( } 8,35 \% \text { of } \\
\text { the sales) }\end{array}$ & \multirow[t]{2}{*}{$\begin{array}{l}\text { Educational activities } \\
\text { Training } \\
\text { Network activities } \\
\text { Support to other } \\
\text { food buying groups } \\
\text { Software (except for } \\
\text { "La Ruche qui dit } \\
\text { Oui") }\end{array}$} \\
\hline & $\begin{array}{l}\text { Social interest } \\
\text { Cooperative } \\
\text { enterprise (CVBA-so: } \\
\text { Belgium, law of } 13 \\
\text { April 1995) }\end{array}$ & $\begin{array}{l}\text { CSA (Community } \\
\text { Supported Agriculture) }\end{array}$ & $\begin{array}{l}\text { To the farmer } \\
\text { (produced food) }\end{array}$ & \\
\hline
\end{tabular}


This role of social enterprises in socio-ecological transitions is supported by the insights of scholars of transition theory, who show the importance of experimental niche innovations operating in so-called protected environments, shielding them from an increasingly fierce and globalized market competition (Grin et al., 2010: chapter 5 of part I). Protected niches can provide the necessary space for a path breaking technology or a radical social innovation to evolve into a more mature form and eventually inspire other transition actors. For instance, in spite of a price-premium paid for the environmental benefits, the higher labour costs per unit of production in the sustainable farming systems remain a challenge in a highly competitive environment (MacRae et al., 2007). In addition, the environmental benefits from local and regional food chains are often offset by weak infrastructure, lower economies of scale, and relatively inefficient distribution channels. In such cases, improved coordination can improve the overall economic sustainability, for instance by improving the efficiency of links between local small-scale producers and consumers. According to the Foodmetres study cited above, the combined environmental sustainability and economic sustainability of CFBGs are highest if they operate in proximity to the consumers (to improve efficiency of transport) and if they support the profitability of the local farm (for instance by reducing distribution and packaging costs or by circumventing intermediaries).

\subsection{The role of social networking for promoting civic learning}

The strong focus on the role of experimental niches has been criticised within transition theory, however. Some socio-technological transition approaches based on change through small-scale niche innovations seem to pay scant attention to the need for support from the broader political context and for the regime to co-evolve with the innovative practices to overcome the lock-in in unsustainable development paths (Schot and Geels, 2008). Indeed, niches can only thrive and develop into alternatives to the mainstream if the political and legal regime opens up opportunities for societal change. Such changes in the political and legal regimes depend in particular on broader socio-cultural changes: in other terms, the "supply" of niche innovations can only further develop if it is matched with an articulated societal "demand" from individual citizens and consumers, which recognize the need for such deeper societal change (Grin et al., 2010, p. 331; Spaargaren et al. 2012).

New challenges emerge once we recognize that niche innovations in agri-food systems only shall be able to grow if supported by broader societal changes. One challenge is how to trigger intrinsic motivation amongst individuals for sustainability practices, rather than only resorting to mechanisms that reinforce extrinsically motivated behaviour (e.g., restrictive regulations, pricing policies, etc.) (Dedeurwaerdere et al., 2016). Indeed, social psychology has amply demonstrated that change that is motivated by the values individuals hold or grounded in their self-image, is far more persistent than change that is directed top-down (Ryan and Deci, 2000a and 2000b). Another important question is how to transform the everyday social practices of individual citizens and consumers (such as cooking, driving, etc.) which are co-constitutive of the socio-technological pathways in which the agri-food system evolve (Spaargaren et al., 2006). Further, how can consumers and citizens be given an active role in the construction of common meanings around the various social, ecological and economic dimensions of more sustainable agri-food systems, based on their knowledge of the specific contexts and socially legitimate pathways of transition (Popa et al., 2012; Seyfang and Smith, 2007)?

The need to promote both experimental niches that can provide collective goods, without being fully exposed to global market competition, and a broader process of social learning on possible lifestyle changes has led to an embedding of the collective food buying groups in social networks that promote 
a strong social transformation agenda. Indeed, the emergence of many of the collective food buying groups has been fostered by the broader social networks of which these initiatives are part to various degrees (Seyfang and Longhurst, 2013; Michel and Hudon, 2015). Notable amongst these are the Transition Towns movement in Northern Europe, the Città-slow movement in the South and the global organic farming movement (Kunze and Becker, 2015, p. 433; Forno et al., 2015).

Unlike the narrower category of community enterprises or local economies, these social networks that link collective food buying groups both to one another and to other transition initiatives are not necessarily local or oriented in priority to a specific community. Rather, they combine innovative forms of non-state collective action to deliver collective goods and services (such as logistic support to sustainable food chains) with explicit aspirations for fostering learning and experimentation for broader societal transformations (Kunze and Becker, 2015, p. 435). They can contribute to regime change in various ways. Indirectly, these decentralized networks can foster regime change through their capacity to inspire social innovations by mainstream actors (Seyfang and Smith, 2007, p. 595), or through their ability to act as "norm entrepreneurs" transforming social norms (Sunstein, 1996). Change can also result more directly from their activities, through building coalitions with regime actors that are willing to contribute to large-scale changes (Geels and Deuten, 2006). Therefore, even though these initiatives seek to bring about social change, this is not necessarily through protest or interest-based lobbying: their strategy for social change is to facilitate and promote concrete life style changes through niche initiatives and to link these initiatives through decentralized social networking (for a similar approach to collective action in other areas, see Diani and McAdam, 2003). Here, we seek to provide empirical evidence of how they implement this strategy, based on an examination of the links between organisational and governance activities of the CFBGs and the motivations of the individuals involved.

\section{Data collection, empirical model and methodology}

\subsection{Survey of collective food buying groups}

We conducted field interviews between December 2014 and July 2015 across 104 collective food buying groups in selected regions throughout Belgium. The sample was built to have a broad diversity of regions, including 3 large urban regions, 2 small-size urban regions and 2 non-urban regions. Because we aimed to identify the operation of potential network effects, a number of food buying groups within a radius of $30 \mathrm{~km}$ were chosen in each region. Further, as illustrated in table 2, a broad variety of organisational types that are representative of the main categories of local and sustainable producer-consumer partnerships was chosen. The questionnaire checked for the viability of the organisations: all the organisations surveyed have an economically stable partnership relation with the producer, and all show a stable or growing membership (the main reason for leaving the group is that people moved out to another place).

During the fields visit, a semi-structured questionnaire was administered, containing 3 open questions and 28 closed questions with pre-defined multiple-choice options. With the exception of 4 interviews with the "Ruches", and 4 interviews with the "GAC", which were conducted by phone, all the interviews were done face to face, each lasting between 45 minutes and 2 hours.

Table 2. Overview of the survey sample, with a specification of the 6 different organisational types 


\begin{tabular}{|l|l|l|l|l|l|l|l|l|}
\hline & Brussels & Antwerp & Liège & Leuven & $\begin{array}{l}\text { Ottignies- } \\
\text { Louvain-la- } \\
\text { Neuve }\end{array}$ & $\begin{array}{l}\text { Non-urban } \\
\text { (Limburg) }\end{array}$ & $\begin{array}{l}\text { Non-urban } \\
\text { (Walloon Region) }\end{array}$ & TOTAL \\
\hline $\begin{array}{l}\text { Number } \\
\text { of } \\
\text { interviews }\end{array}$ & 14 & 15 & 17 & 21 & 12 & 6 & 14 & 104 \\
\hline
\end{tabular}

\begin{tabular}{|c|c|c|c|}
\hline & Key features & $\begin{array}{l}\text { Number } \\
\text { of } \\
\text { interviews }\end{array}$ & $\begin{array}{l}\text { Total } \\
\text { number of } \\
\text { organisatio } \\
\text { ns in } \\
\text { Belgium }\end{array}$ \\
\hline $\begin{array}{l}\text { Voedselteams (Leuven, Antwerp (both urban), and Limburg } \\
\text { (non-urban)) }\end{array}$ & $\begin{array}{l}\text { System of weekly orders, strong } \\
\text { umbrella organisation that provide } \\
\text { support for software and identification } \\
\text { of new producers (membership fee of } 15 \\
\text { euros/year) }\end{array}$ & 35 & $\begin{array}{l}175 \text { (Oct. } \\
2015)\end{array}$ \\
\hline $\begin{array}{l}\text { GAC : Groupes d'achat commun (Brussels, Ottignies- } \\
\text { Louvain-la-Neuve (both urban), Walloon Region (non- } \\
\text { urban)) }\end{array}$ & $\begin{array}{l}\text { System of weekly orders, loose } \\
\text { federation }\end{array}$ & 42 & $\begin{array}{l}148 \\
\text { (including } \\
\text { AMAP, Oct } \\
\text { 2015) }\end{array}$ \\
\hline $\begin{array}{l}\text { GASAP : Groupes d'achat solidaires de l'agriculture } \\
\text { paysanne (Brussels (urban)) }\end{array}$ & $\begin{array}{l}\text { System of solidarity contract with the } \\
\text { farmer (usually } 1 \text { year contract), strong } \\
\text { umbrella organization, no membership } \\
\text { fee }\end{array}$ & 10 & $\begin{array}{l}74 \text { (June } \\
2014)\end{array}$ \\
\hline $\begin{array}{l}\text { CSA: Community-supported agriculture (Antwerp, Leuven } \\
\text { (both urban)) }\end{array}$ & $\begin{array}{l}\text { System of solidarity contract with the } \\
\text { farmer (usually } 1 \text { year contract), loose } \\
\text { federation, members also contribute to } \\
\text { harvesting }\end{array}$ & 8 & $\begin{array}{l}31 \text { (Oct. } \\
2015)\end{array}$ \\
\hline $\begin{array}{l}\text { Ruches : La Ruche qui dit Oui (Brussels, Ottignies-Louvain-la- } \\
\text { Neuve (both urban), Walloon Region (non-urban)) }\end{array}$ & $\begin{array}{l}\text { System of weekly orders, strong } \\
\text { umbrella organisation structured as a } \\
\text { social enterprise (Entreprise Solidaire } \\
d^{\prime} \text { Utilité Sociale), } 8,35 \% \text { of the price paid } \\
\text { by the consumer goes to the umbrella } \\
\text { organisation }\end{array}$ & 7 & $\begin{array}{l}53 \text { (Oct. } \\
2015)\end{array}$ \\
\hline $\begin{array}{l}\text { AMAP : Association pour le maintien de l'agriculture } \\
\text { paysanne (Ottignies-Louvain-la-Neuve (urban), Walloon } \\
\text { Region (non-urban)) }\end{array}$ & $\begin{array}{l}\text { System of solidarity contract with the } \\
\text { farmer (usually } 1 \text { year contract), loose } \\
\text { federation, no membership fee }\end{array}$ & 2 & $\begin{array}{l}\text { (included } \\
\text { above) }\end{array}$ \\
\hline TOTAL & & 104 & 481 \\
\hline
\end{tabular}

\subsection{Specification of the hypothesis and empirical model}

The key hypothesis of the paper is that the activities of the collective food buying groups combine two components, in varying proportions in each group, and that these distinct aims call for different modes of governance and kinds of support. Our sample includes both organisations that more actively promote the goals of changing the agri-food systems (the social network component, oriented towards social learning on more sustainable farming systems) and organisations that have a more functional orientation, geared towards the provision of services (through the non-profit service component, oriented towards enlisting consumers in more sustainable consumption patterns). In the sample of CFBGs that was surveyed, the social network component is represented by organisations that give higher priority to the transformation of the farming systems, while the social enterprise component is 
represented by organisations that give higher priority to providing tasty and healthy food from sustainable agriculture to the consumers. As shown in table 3 these two orientations are more or less equally represented in our research sample.

Table 3. Hybrid nature of the collective food buying groups (table based on the answers on question 28, which offered to indicate what objective is the first priority of the collective Food Buying Group (CFBG), amongst the three options described in the first column).

\begin{tabular}{|l|l|l|l|l|l|l|}
\hline & $\begin{array}{l}\text { Voedsel- } \\
\text { teams }\end{array}$ & CSA & GASAP & GACs & Ruches & Amap \\
\hline Total number in sample : 104 & 35 & 8 & 10 & 42 & 7 & 2 \\
\hline $\begin{array}{l}\text { First priority/3: supporting the farmers that } \\
\text { supply the CFBG (q28a) (average: 41\%) }\end{array}$ & $31 \%$ & $38 \%$ & $60 \%$ & $38 \%$ & $71 \%$ & $100 \%$ \\
\hline $\begin{array}{l}\text { First priority/3: providing tasty, healthy, } \\
\text { sustainable and affordable food to the } \\
\text { members of the CFBG (q28b) (average: 52\%) }\end{array}$ & $63 \%$ & $50 \%$ & $30 \%$ & $55 \%$ & $29 \%$ & $0 \%$ \\
\hline $\begin{array}{l}\text { First priority/3: creating a participatory } \\
\text { dynamics around food for the CFBG members } \\
\text { (q28c) (average: 7\%) }\end{array}$ & $6 \%$ & $12 \%$ & $10 \%$ & $7 \%$ & $0 \%$ & $0 \%$ \\
\hline
\end{tabular}

A set of research questions emerge once we take into account the hybrid nature (social enterprise and social network) of the organisations surveyed. Indeed, key issues such as the mobilisation of resources for their functioning and the mechanisms to enlist and commit members have hardly been subject to a systematic empirical assessment. One notable exception is the study of hybrids between non-profits and social movements for peace and reconciliation in South Africa (Hasenfeld and Gidron, 2005, p. 105-107). In this case, researchers showed that members of hybrids typically gather around common social values, mobilise resources through accessing social networks and connecting with organisations that control important resources (including members, funds, legitimacy, and technical expertise), and build social capital by responding to the expressive and social identity needs of their members. The qualitative assessment of sustainable food chains in major EU city areas (Foodmeters, 2014) also highlighted the importance of these features, even though the "social capital" aspects appear to be less important in some of the studies (Berehm and Eisenhauer, 2008).

To assess the role of these variables in the explanation of the governance specificities of the social movement and the social enterprise components, two regression models were developed, based on the responses to the multiple choice options of the close-end part of the semi-structured questionnaire. The first regression model focuses on resource mobilisation and commitment, while the second model focuses on direct and indirect policy support.

More specifically, the first model tests if giving priority to "Transforming farming systems" as compared to the individual consumer oriented priority "Sustainable food distribution" in the overall mission of the food buying group is significantly correlated with (details on the exact definition of the variables is given in annex 1):

- Resource mobilisation

○ the use of shared buildings for food deposit from food transition related associations (variable: Resources food transition assoc)

0 the use of shared economic and knowledge resources from other environmental/social associations (variable: Resources other assoc),

- self-organisation for technical advice on the functional activities (variable: Members consulted for practical advice) 
- social networking with other, nearby, food buying groups (variable: CFBG social networking)

- Commitment

- the organisation of convivial events (variable: Convivial events)

$\circ$ the distribution of a newsletter (variable: Newsletter)

- social networking with transition towns, which have also a prominent social movement agenda for changing the agri-food system (variable: Netw transition towns)

- Control

0 the members see the organisation as struggling against the existing food system (variable: Reform of the food system), as opposed to two other options presented in the questionnaire: building a different food system (that is: creating alternatives to the mainstream marketing channels) and improving the existing food system.

The second model tests if giving priority to "Supporting sustainable farming practices" (as compared to the more consumer oriented objective of "Supporting local food schemes") as the most important objective for building relationship to the farmers is significantly correlated with (details on the exact definition of the variables is given in annex 1):

- Support needed for the emergence/development of the alternative food networks

- Political support for assigning higher priority to the CFBG in the food system (variable: Political legitimacy)

- Technical support in terms of software, logistical advice, etc. (variable: Technical support)

- Political support by organising a specific administrative service (variable: Administrative service)

- Resource mobilisation

- The use of shared economic and knowledge resources from food transition associations (variable: Resources food transition assoc),

- Distribution of the organisational tasks for the functional activities amongst the members (variable: Members mobilised for functional activities)

- Absence of social networking with other, nearby, CFBG's (variable: No CFBG social networking)

- Control

- My own CFBG builds a different food system (variable: Building different food system)

Control variables pertaining to the influence of the location of the initiative in one of the 7 regions, the organisational types and the role of the interviewee (as a core manager in the Food Buying Group) were included in the analysis.

\subsection{Data analysis method}

The outcome variables can reasonably be represented by binary response variables (closed questions 28 and 29 of the questionnaire). We therefore estimated the correlations with the outcome variables through a binary probit model. The statistical software package Stata 13.1 was used to perform the analysis. We used the svy ("survey") set command in stata, with the following parameters: $p w=481$ ("pweight"=number of observations in the population, see table 2); fpc=104 ("finite population correction" = number of sampling units). The original survey data will be made available online and can be retrieved through a search for the paper title on the EU open access infrastructure for research data zenodo (www.zenodo.org). 


\section{Governing social networking in collective food buying groups}

The following subsection first shortly presents the common features cutting across the collective food buying groups that emerge from the analysis of the semi-structured questionnaire. We then present the regression analyses on the specific governance features of each of the two components of the hybrid social enterprise/social network organisational form.

\subsection{Common features of the collective food buying groups}

Collective food buying groups combine the technological ability of easy manageable internet portals for managing food buying groups, with a solidarity arrangement with sustainable farmers and an involvement of citizens in civic learning. As such these partnerships are expected to feature two characteristics. First, they are expected to give a central role to the farmer in the social network that is built around the collective food buying group. Second, they should provide a variety of tools that favour a certain degree of participation in decision making.

These two features are confirmed by the descriptive data of the survey. First, when inquiring into the most influential organisations for shaping beliefs of the CFBG, the farmer comes out systematically first for the vast majority of the CFBGs, far above other options such as local authorities, social organisations or other CFBGs (cf. table 4). Second, the majority of the CFBGs convene a general assembly meeting on a frequent basis ( $64.7 \%$ of all the CFBG), rely on mailing lists ( $82.4 \%$ of all the CFBGs), or organise convivial events amongst the members $(64.7 \%)$, to foster participation and involvement of the members.

Table 4. The most influential organisations for shaping beliefs on agri-food transition highlighted by the coordinators of the Food Buying Groups (CFBG) (Q34 of the survey)

\begin{tabular}{|l|l|l|l|l|}
\hline & $\begin{array}{l}\text { No influence } \\
(\%)\end{array}$ & $\begin{array}{l}\text { Influence } \\
(\%)\end{array}$ & $\begin{array}{l}\text { Don't know or n/a } \\
(\%)\end{array}$ & $\begin{array}{l}\text { Total } \\
\text { respondents }\end{array}$ \\
\hline The first closest CFBG to yours & 36 & 45 & 16 & 97 \\
\hline The second closest CFBG to yours & 32 & 36 & 29 & 97 \\
\hline Your main supplier & 7 & 92 & 1 & 100 \\
\hline Local groceries, cooperatives and local market & 49 & 46 & 4 & 99 \\
\hline Supermarkets & 84 & 13 & 0 & 97 \\
\hline Local authorities & 76 & 22 & 1 & 99 \\
\hline National or regional governments & 81 & 15 & 1 & 97 \\
\hline EU level governments & 81 & 14 & 2 & 97 \\
\hline $\begin{array}{l}\text { Social organisations: mutual insurance organisation, } \\
\text { medical centre, municipal social services }\end{array}$ & 72 & 13 & 12 & 97 \\
\hline
\end{tabular}

\subsection{Governance features related to the social enterprise service activities and the social network activities}

\subsubsection{Presentation of the results}

Table 5 and 6 show the results of the two regression models. Table 5 presents the correlations with key governance features of the food buying groups, related to resource mobilisation and commitment, while table 6 presents the correlations with key governance features related to resource mobilisation and policy support. 
Table 5. Results of the probit estimations on governance features related to resource mobilisation and commitment (technical specification of the variables and descriptive statistics in annex 1).

\begin{tabular}{|c|c|c|c|c|c|c|c|}
\hline & & \multicolumn{6}{|c|}{ Dependent variables } \\
\hline & & \multicolumn{3}{|c|}{$\begin{array}{l}\text { M1: Transform Farming Systems } \\
\text { as CFBG's Priority Objective (in } \\
\text { general) }\end{array}$} & \multicolumn{3}{|c|}{$\begin{array}{l}\text { M2 : Sustainable Food Distribution } \\
\text { as CFBG's Priority Objective (in } \\
\text { general) }\end{array}$} \\
\hline \multicolumn{8}{|c|}{ Independent variables } \\
\hline & & Signif & Coef. & St.err. & Signif. & Coef. & St.err. \\
\hline \multirow{4}{*}{$\begin{array}{l}\text { Resource } \\
\text { mobilisation }\end{array}$} & Resources food transition assoc & $(+)^{* * *}$ & 1.8844 & 0.3994 & $(-)^{* * *}$ & -1.6642 & 0.4155 \\
\hline & Resources other assoc & $(-)^{* * *}$ & -0.7214 & 0.2707 & $(+)^{* *}$ & 0.5401 & 0.2670 \\
\hline & Members consulted for practical advice & $(-)^{*}$ & -0.5513 & 0.2782 & $(+)^{* * *}$ & 0.9238 & 0.2829 \\
\hline & CFBG social networking & $(+)^{*}$ & 0,4780 & 0.2543 & $(-)$ & -0.4197 & 0.2563 \\
\hline \multirow[t]{3}{*}{ Commitment } & Convivial events & $(+)^{* *}$ & 0,5508 & 0.2716 & $(-)$ & -0.2864 & 0.2629 \\
\hline & Newsletter & $(+)^{* *}$ & 0.6362 & 0.3032 & $(-)^{*}$ & -0.5095 & 0.2942 \\
\hline & Netw transition towns & $(+)^{*}$ & 0.5139 & 0.2659 & $(-)^{* *}$ & -0.5743 & 0.2630 \\
\hline \multicolumn{8}{|c|}{ Control variable } \\
\hline & $\begin{array}{l}\text { My own CFBG struggles against the } \\
\text { existing food system }\end{array}$ & $(-)^{* * *}$ & $-1,6099$ & 0.5457 & $(+)^{* * *}$ & 1.4549 & 0.4748 \\
\hline & & \multicolumn{3}{|c|}{ Prob $>F=0.0000$} & \multicolumn{3}{|c|}{ Prob $>F=0.0001$} \\
\hline
\end{tabular}

Table 6. Results of the probit estimations of governance features related to resource mobilisation and policy support (technical specification of the variables and descriptive statistics in annex 1).

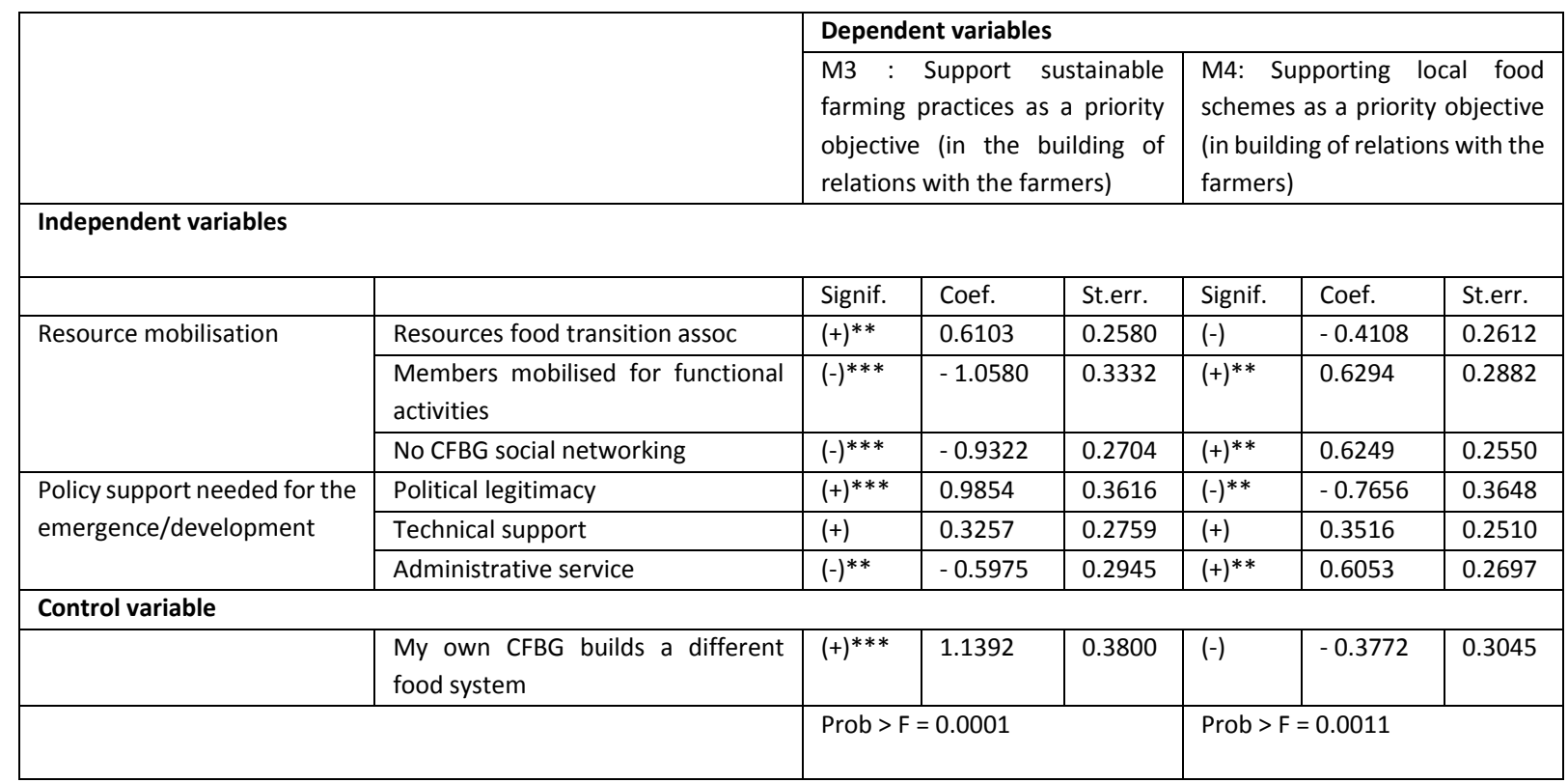

Significant at $10 \%$ level $(*), 5 \%$ level $(* *)$, at $1 \%$ level $(* * *)$.

\subsubsection{Discussion of the regression results}

We first discuss the variables that are at least significant at the $1 \%$ level in one of the four models. In the second section we then discuss the variables that are significant at the $5 \%$ level in one the four models.

(a) Most significant variables at $1 \%$ level in at least one of the regressions 
The general outcome of the survey confirms the extent to which the social network component and the social enterprise service provision component of the alternative food networks rely on different governance systems. The most significant difference lies in the way resources are mobilised from other organisations. The use of buildings (meeting rooms, deposit space, etc.) from food transition related associations that are made available through sharing arrangements (variable "Resources food transition assoc") is positively correlated with the social network component. Along the same line, the absence of social networks with other Food Buying Groups (variable "No CFBG social networking") is negatively correlated with the social network component. These results are consistent with the theoretical models reviewed above which highlight the importance of inter-organisational networking within the social movement as a key element of autonomous resource mobilisation in favour of a radical transformation of the production system. On the other hand, the variable "Resources other associations" (which refers to the use of economic and knowledge resources from, or shared with, other environmental/social associations) is significantly correlated with the social enterprise component. No significant difference between the two components is observed in relation to the other organisations that are strongly involved in the sharing of resources in the local food networks, but which are unrelated to the social network component (such as sharing of resources with local authorities or local groceries).

A second set of features with highly significant correlations is related to the organisation of the social enterprise component. Both the variable related to the requesting of advice to the own members ("Members consulted for practical advice") and the variable related to the distribution of general organisational tasks (accounting, invitation for the meetings, organisation of the collection point, etc.) across the members (variable "Members mobilised for functional activities") are positively correlated with the social enterprise component. The latter reflects the light, functional governance system that characterises the service provision component of the Food Buying Groups.

The two regression models also show significant differences concerning the need for policy support (as formulated by the organisations' coordinators) and enabling governance features that stimulate members' commitment to the organisation. The variable "Political legitimacy" is positively correlated to the social network component. This variable indicates that respondents highlighted policy support in terms of assigning "higher priority to Food Buying Groups within the food system" as the most important kind of support, as compared to five other options that were proposed to the interviewee (which were respectively related to financial, administrative, technical, legal and information sharing/political lobbying support). Interestingly, this variable fits well with the general nature of the hybrid organisations, which strives to change the legal and political food-regime through the development of innovative niche activities, instead of the more conventional lobbying and advocacy channels.

Finally, the survey also "controlled" for the general orientation of the organisation in relation to the food system, by proposing three options: gradual improvement, internal reform or building a different system. In the overall sample, $79 \%$ of the respondents indicated that they consider that their Food Buying Group is "building a different system", in line with the overall strategy of the collective food buying groups of creating alternatives to the mainstream system. Only $12 \%$ of the overall sample indicated that they consider that their group struggles against the existing food system (13 respondents, 11 of these belonging to the social enterprise component). As might be expected, the social network component is correlated with the building of a different system, while the social 
enterprise component is correlated with the group of respondents striving for internal reform. The latter might be related to the fact that organisations with a more explicit social enterprise orientation are more directly concerned by removing obstacles created by the existing system, for the expansion of their service activities (for example by making sustainable farming products comparatively more competitive).

(b) Most significant variables at the $5 \%$ level in at least one of the regressions

Organising a specific administrative service with councillors/researchers/advisers by the government is highlighted as a highly needed form of governance support by the respondents of the social enterprise component. This is consistent with the need for general social infrastructures as highlighted in the literature.

In terms of commitment, the social network component is correlated with the organisation of activities with transition movements (which originated with the network of Transition Towns). This allows to contribute to building shared values among the members, in relation to the transition agenda of the Transition Network, which is highlighted as an important element of successfully building social networks in the literature. Along the same lines, the organisation of convivial events and the distribution of a newsletter is also correlated with the social network component.

Finally, the results on the variable "Resources food transition assoc" are consistent with the results discussed above for the variables that are significant at the $1 \%$ level.

\subsubsection{Social enterprise and social network organisational forms}

Based on these in depth cases studies and the results of our regressions, we suggest three types of governance features that play a role in the operation of the collective food buying groups: various forms of direct/indirect policy support, resource mobilisation from non-market resources in support of their activities and the development of specific strategies to register and commit members. 
Direct and indirect

policy support

Resource mobilization

Commitment
Political legitimacy (political allies for the alternative food networks)

Inter-organisational linkages with other agri-food transition movements

\section{Build new system}

Promote civic learning

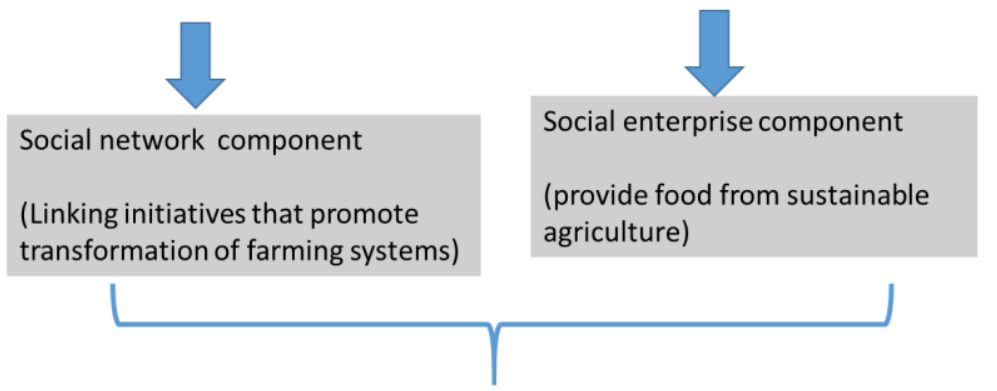

Inter-organisational linkages with other collective food buying groups

Reform existing system

Members involved in service activities

\begin{abstract}
Sustainable consumer-producer partnerships (common social value: solidarity with sustainable, small-scale farmer)
\end{abstract}

Figure 1. Collective food buying groups as a hybrid social enterprise/social network organisational form

Figure 1 schematically represents the main specificities of the organisational forms of the two components that we have analysed. For the social network component, the mobilisation of resources is done through linkages with other niche innovations that promote learning on agri-food transitions and the political recognition of the important role of experimentation with more radical lifestyle changes. Indeed, social networks around sustainability transitions are more likely to emerge when the political system when the organisations have access to some elite allies that support their cause. At the same time, support from other social movements active in promoting the agri-food transition may be necessary to guarantee sufficient autonomy from an overly strong political interference, for example through enhancing their financial autonomy by sharing resources in kind with other organisations (in terms of sharing of staff, sharing of buildings, etc.).

In contrast, the social enterprise service component is more likely to depend on generic technical or administrative support for the development of the voluntary service activities related to the packaging, distribution and selling of the sustainable food products. Further, resources in support of these activities can be mobilised through forming alliances with organisations that are not necessarily focused on the transition in the agri-food sector, although they may also take concrete action for the building of more sustainable food systems (such as fair trade organisations putting food collecting space at the disposal of the CFBG, or social integration organizations that distribute the newsletters/contacts for the recruitment of new potential members).

The two components of the alternative food networks also show contrasting features in relation to the commitment of their members. Although face to face contacts are likely to be important in both components, members' meetings and information on the activities are more actively promoted in the social network component. This is in line with the social movements' literature, which highlights the importance of the building of common frames of analysis across the members (Benford and Snow, 2000; Polletta and Jasper, 2001). In the social enterprise component, membership contacts are important as well, but they are more related to the organisation of the voluntary services by the food buying group. 


\section{Consequences for the role of decentralized social networking in agri-food transitions}

Two major challenges for the operation of collective food buying groups were discussed in this paper. First, these organisations are searching for mechanisms to increase the local and regional supply of sustainable farm products, by supporting farmers involved in low-input, agro-ecological or organic farming systems or by supporting the conversion of farmers to such systems. Secondly, these initiatives aim to promote broader social learning on possible lifestyle changes for transition to sustainable agrifood systems, in particular by linking to other initiatives involved in social learning around such lifestyle changes through information sharing, knowledge exchange and common activities.

As shown in this paper, organisational networks of collective food buying groups address this twin challenge by a hybridisation of a social enterprise component, focused on service provision for the organisation of the sustainable food short chains (such as through mobilizing voluntary labour for collection and distribution), and a social network component, focused on the information sharing and joint activities. More specifically, each food buying group includes members from within each component, even if each organisation will put a stronger emphasis overall on one or the other dimension as shown through the survey.

Two general results can be established from the analysis. First, as highlighted in the introduction, an important element of the social network component is the construction of social and ecological sustainability transitions as a multi-dimensional concept, which goes far beyond the "local market" or "fresh and healthy" dimensions only. This is especially important, as this multi-dimensional interpretation of sustainability has to compete for instance with a growing discourse of economic nationalism/regionalism that focuses on local economic production, without however necessarily integrating the ecological and social dimensions. For instance, cheese from a local high input largescale industrial provider can be promoted with a "regional" label, in spite of the fact that such local sourcing is not related to sustainable consumption and/or production methods.

The broader orientation of the collective food buying groups, beyond the discourse of economic nationalism/regionalism or satisfaction of individual consumer preferences, is confirmed by the survey results. In particular, the coordinators of the groups indicated that experimenting with sustainable lifestyle changes is one of the most important objectives of the organization (question 31), and they rank support to sustainable farming practices higher than the promotion of short circuits (question 29). This is also reflected in the composition of the food baskets, which often complement the local supply in sustainable farming products with organic products from a regional wholesaler if these are not otherwise available. In addition, the question on the social networks of influence in the shaping of beliefs clearly shows the multi-dimensional nature of this process. Not only "local" or "healthy" food related organizations, such as the small-scale farmer and the local groceries, rank high in the organizations with major influence. Other organizations such as organizations promoting sustainable agriculture, fair trade or social organizations are mentioned as having a major influence (question 34 and 51). Further, in a substantial number of the CFBGs that were interviewed, this social networking extends to explicit linkage to broader clusters of social and ecological initiatives, in particular with the transition movement (cf. correlation results in table 5). 
Second, the groups largely favour decentralized modes of coordination for organizing the social network component. These decentralized networks play a role in the information sharing and cooperation around activities of alternative food networks, but also in the dissemination and exchange of information on organizational tools to set up and develop collective food buying groups. In relation to the social learning networks around lifestyle changes, centralized network connections with national or regional authorities rank very low, both for the questions on trust and influence (questions 27 and 34). In contrast, decentralized networks, such as networking with nearby collective food buying groups, local groceries and other food transition associations all rank very high in the declared relationships of trust and influence. In relation to the dissemination of the organisational tools, legal and organisational advice from peers is preferred to expert advice or advice from public administrations (question 17 and 37).

These insights on the collective learning on multi-dimensional approaches to sustainable agri-food systems, and the role of decentralized networking in fostering collective learning, hint to some governance recommendations for the operation of the collective food buying groups. The choice of organisational structure is not a sufficient condition for a fruitful combination of the social enterprise and the social network components. As shown by the questionnaire results, the choice of a social cooperative organisation of the type "community supported agriculture" (CSA) is no guarantee for a successful implementation of the social network component. Indeed, some organisations in the CSA sub-sample are stronger on the social networking than others. Conversely, the choice of a more commercially oriented social enterprise such as "La ruche qui dit Oui" does not preclude the possibility for successfully addressing the social network aspects. Rather than organisational form as such, therefore, the key feature for a successful hybridisation seems to be to ability to embed a certain organisational choice in the broader social network of organisations experimenting and learning on lifestyle changes for sustainable agri-food systems. Such embedding can be the results of information sharing or the organisation of joint activities with other sustainable food related organisations, such as local groceries and cooperatives, but can also lead to more integrated forms such as the participation in the activities of the transition groups.

Finally, the governance requirements of the hybrid social network/social enterprise components of the collective food buying groups also indicate some questions for further research. In particular, scholars of non-state collective action have shown the important role of network bridging organisations in collaborative social networks amongst private not-for-profit and public sector actors (Berkes, 2009; Dedeurwaerdere, 2015). Such network bridging organisations include regional platforms, umbrella organisations or knowledge hubs, among others. These organisations fulfil various roles that are key to the building of the cooperative action amongst the various social actors that drive the transition initiatives.

The results of the analysis in this paper points to two important categories of tasks for such network bridging organisations in the case of alternative food networks. First, as can be seen from the survey, various governance means are specifically needed for developing the social enterprise service activities component. Many local and regional food networks still suffer from inefficient distribution channels, lack of administrative support and poor infrastructure. Umbrella organisations, supported both by public authorities and members' fees, can step in to overcome some of these insufficiencies. For example, in one of the cases analysed in this paper, the Voedselteams vzw (cf. table 2) is a strong umbrella organisation supporting the local groups in the search for suppliers located within their 
vicinity. This kind of support (helping to identify local producers) is strongly correlated in the survey with the trust expressed by the local CFBGs in the umbrella organisations (respectively questions 17 and 27 of the survey). In another prominent example, the case of the Seikatsu Club, the umbrella organisation coordinates the consumer demand for products other than fruits and vegetables and organizes the transport of these products from the producers to the collective food buying groups in the most efficient manner (Seikatsuclub.coop/about/english.html).

A second category of tasks for umbrella organisations that can be related to the outcomes of this research is the support for decentralized network activities related to social learning amongst the food buying groups and with other sustainable food associations. In contrast to the more conventional supporting activities in terms of exchange of best practices, administrative support and legal advice, this collaborative aspect is often less straightforward. Indeed, as also shown elsewhere, successful social learning in networks of non-state collective actors depends on "process" dimensions such as non-coercive deliberation and inclusive participation (Innes and Booher, 2003). An interesting example of a network bridging organisation operating along these lines is the "Endogenous Regional Development" programme supported by the regional authorities in Austria (Petrovics et al., 2010). This programme is explicitly geared towards supporting social enterprises for regional sustainability transitions, but it also includes an important aspect of regional and supra-regional dialogue between the initiatives. Another example is the role of the "Grand Projet Rhône-Alpes" in the Val de Drôme in Southern France, where support for non-profit and for profit enterprises involved in ecological activities was combined with a collaborative networking of all the actors in a specific territory (Lamine et al., 2014; De Schutter et al., 2016). In the case study area that was the focus of this paper, potential network organisations that operate along these lines are the "Ceinture alimen-terre Liégeoise" (www.catl.be) and the forum "Gent en Garde" (https://gentengarde.stad.gent). However, further research is needed to document the effects of these organisations on the development of the local food networks and to better understand the various governance and complex process management needs of the collaborative tools established in such larger-scale social learning processes.

\section{Conclusion}

This paper analysed the contribution of hybrid organisational strategies in collective food buying groups, based on synergies between social enterprise and social network activities, with a view to fostering learning on transitions towards more sustainable agri-food systems. Transition initiatives are usually described in the literature as requiring the nurturing of protective innovation niches, where initiatives are not yet fully exposed to the market pressure so that they can evolve towards a mature stage. The social enterprise component of the collective food buying groups provides for such a protective niche, by mobilizing a diverse set of resources ranging from voluntary contributions to various logistic tasks or the free availability of storage space. At the same time, however, considering the scientific uncertainty around the appropriate future transition pathways, transition is an open and experimental process that relies on the pro-active learning on a variety of options and ways of constructing the meaning of sustainable agri-food systems in a multi-dimensional framework. Therefore, the collective food buying groups also invest a substantial amount of time and effort in linking with other food transition organisations, through information exchange and joint activities.

To analyse such hybrid organisational strategies, the paper presented the results of a survey with a semi-structured questionnaire administered through face to face interviews to 104 collective food 
buying groups in Belgium. The main finding of the paper is the existence of different governance needs related to the two components. The social enterprise component is focused on the economic sustainability of the logistics for local and sustainable food provisioning, mainly through functional relationships with other organisations and the development of administrative support. In contrast, the social network component is focused on promoting learning on initiatives for the broader transformation of the agri-food systems. This second component is based on the building of decentralized social networks with "peer" initiatives developed by other local food buying groups, local groceries, public markets and cooperatives or even fair trade and local social organisations. In addition, the comparative analysis of the food buying groups clearly indicate that the hybridisation of these two components is not specific to any one type of consumer-producer organisational form, but has been found across the various organisational types that were analysed, ranging from community supported agriculture to a web-based facilitated collective food buying group organized as a limited profit social enterprise.

While the study needs to be further substantiated through additional comparative research on other initiatives in the agri-food systems, such as related to retail, whole sale or food processing, the analysis provides strong evidence for the successful promotion of social learning on possible alternatives through hybrid social enterprise/social network organisational forms. Questions for further research are the kind of governance support that can be offered by the network bridging organisations that play an active role in promoting the collective food buying groups (such as umbrella organisations or knowledge hubs for a variety of citizen-led transition initiatives). The various roles of network bridging organisations might include support for network activities related to the social learning amongst social enterprise based transition initiatives, in addition to the more conventional supporting activities in terms of exchange of best practices, administrative support and legal advice. It is unlikely, however, that any one kind of tool or policy mechanism will suffice to ensure the stable provision of such support. Therefore, the overall goal of the analysis is to stimulate reflection on the appropriate combination of various mechanisms in supporting the transition of agri-food systems analysed in this paper.

\section{Author contributions}

The text was written by Tom Dedeurwaerdere, Olivier De Schutter, Marek Hudon and Erik Mathijs. Tom Dedeurwaerdere conducted the statistical analysis. The other authors selected the cases, contributed to the design of the survey protocol through a series of common field-work design workshops and conducted the interviews. All authors endorsed the presentation and interpretation of the field work data and approved the final manuscript.

\section{Acknowledgements}

We acknowledge co-funding of this research from the Belgian Science Policy, under the project FOOD4SUSTAINABILITY (contract BR/121/A5), and co-funding from the European Commission, under the project GENCOMMONS (ERC grant agreement 284).

\section{References}

Alaimo, K. (2008). Fruit and Vegetable Intake among Urban Community Gardeners. Journal of Nutrition Education and Behavior 40 (2): 94-101. 
Allen IV, J.E., Rossi, J., Woods, T.A. \& Davis, A.F. (2016): Do Community Supported Agriculture programmes encourage change to food lifestyle behaviours and health outcomes? New evidence from shareholders, International Journal of Agricultural Sustainability, DOI: 10.1080/14735903.2016.1177866

Anheier, H. K. (2005). Nonprofit organizations: Theory, management, policy. Routledge.

Benford, R. D., Snow, D. A. (2000). Framing processes and social movements: An overview and assessment. Annual review of sociology 26: 611-639.

Berehm, Joan M, Eisenhauer B. W. (2008). Motivations for Participating in Community Supported Agriculture and Their Relationship with Community Attachment and Social Capital. Southern Rural Sociology 23(1): 94-115.

Berkes, F. (2009). Evolution of co-management: role of knowledge generation, bridging organizations and social learning. J. Environ. Manag 90.

Bloemmen M., Bobulescu,R. Le, N., Vitari C. (2015). Microeconomic degrowth: The case of Community Supported Agriculture. Ecological Economics 112: 110-115

Borzaga, C., Defourny, J., eds (2001). The Emergence of Social Enterprise, Routledge, London.

Bougherara D., Grolleau G. and Mzoughi N. (2009). Buy local, pollute less: What drives house-holds to join a community supported farm? Ecological Economics 68: 1488-1495

Brumauld, N, Bolazzi F. (2014). Etude comparative du prix des fruits et légumes biologiques en Circuit Court Solidaire Sans Intermédiaire (CCSSI) et en grande distribution. Les Paniers Marseillais et Agribio Alpes Maritimes.

Chell, E. (2007). Social enterprise and entrepreneurship: towards a convergent theory of the entrepreneurial process, International Small Business Journal 25, 5-26.

Connelly, S., Markey, S., Roseland, M. (2011). Bridging sustainability and the social economy: achieving community transformation through local food initaitives. Critical Social Policy 31(2) :308-324.

Cooley, J.P. and D.A. Lass. (1998). Consumer Benefits from Community Supported Agriculture Membership. Review of Agricultural Economics 20(1): 227-37.

David-Leroy, M., Girou S. (2009). AMAP. Association pour le Maintien d'une Agriculture Paysanne. Replaçons l'Alimentation au Cœur de nos Sociétés. Paris.

De Schutter, O. (2014). Final Report: The transformative potential of the right to food. Report of the Special Rapporteur on the right to food. UN: A/HRC/25/57.

De Schutter, O., Bui, S., Cassiers, I., Dedeurwaerdere, T., Galand, B., Jeanmart, H., Nyssens, M. et Verhaegen, E. 2016. Construire la transition par l'innovation locale : le cas de la Vallée de la Drôme. LPTransition Working Paper 2016-1. Available on line at http://Iptransition.uclouvain.be.

Dedeurwaerdere, T., Admiraal, J., Beringer, A., Bonaiuto, F., Cicero, L., Fernandez-Wulff, P and Melindi-Ghidi, P. (2016). Combining internal and external motivations in multi-actor governance arrangements for biodiversity and ecosystem services. Environmental Science \& Policy, 58, 1-10

Dedeurwaerdere, T., Polard, A. and Melindi-Ghidi, P. (2015). The role of network bridging organisations in compensation payments for agri-environmental services under the EU Common Agricultural Policy, Ecological Economics, 119: 24-38

Defourny, J. \& Nyssens, M. (2010). Conceptions of Social Enterprise and Social Entrepreneurship in Europe and the United States: Convergences and Divergences, Journal of Social Entrepreneurship 1, 32-53. 
Diani, M., \& McAdam, D. (2003). Social movements and networks: Relational approaches to collective action. Oxford University Press.

D'Silva, J., Webster, J. (eds) (2010). The Meat Crisis. Developing More Sustainable Production and Consumption, Earthscan, London and Washington, D.C.

Dunning, R. (2013). Research-Based Support and Extension Outreach for Local Food Systems. Center for Environmental Farming Systems.

Fici, A. (2015). Recognition and Legal Forms of Social Enterprise in Europe: a Critical Analysis from a Comparative Law Perspective, Euricse Working Papers, 82/15.

Foodmetres (2014). Metropolitan Footprint Analysis and Sustainability Impact Assessment of Short Food Chain Scenarios. D5.1 of the project. Available at http://www.foodmetres.eu/.

Forno, F., Grasseni, C., Signori, S. 2015. Italy's Solidarity Purchase Groups as “citizenship labs”. In: E.H. Kenney, M.J. Cohen, N. Krogman, Putting Sustainability into Practice. Edward Elgar, 2015.

Grin, J, Rotmans, J., Schot, J. (2010). Transitions to Sustainable Development. Routledge.

Groh, T. and McFadden, S. (2004). Farms of Tomorrow Revisited: Community Supported Farms, Farm Supported Communities. San Francisco: Biodynamic Farming and Gardening Association ; on line, http://newfarm.rodaleinstitute.org/features/0104/csa-history/part1.shtml

Hasenfeld, Y, Gidron, B. (2005). Understanding multi-purpose hybrid voluntary organisations: The contributions of Theories on Civil Society, Social Movements and Non-profit Organisations. Journal of Civil Society 1(2): 97112.

Innes, J. E., Booher, D. E. (2003). Collaborative policymaking: governance through dialogue. In: M. Hajer and H. Wagenaar (Eds.), Deliberative policy analysis: Understanding governance in the network society. Cambridge University Press., Cambridge, UK, pp. 33-59.

Johanisova N., Crabtree, T., Frankova E. 2013. Social enterprises and non-market capitals: a path to degrowth ? Journal of Cleaner Production 38, 7-16.

King, R. P., Hand, M. S., DiGiacomo, G., Clancy, K., Gómez, M. I., Hardesty, S. D., McLaughlin, E. W. (2011). Comparing the structure, size and performance of local and mainstream food supply chains (Economic Research Report ERR-99). Economic Research Service, U.S. Department of Agriculture, Washington DC.

Kunze, C. and S. Becker. 2015. Collective ownership in renewable energy and opportunities for sustainable degrowth. Sustainability Science 10 (3): 425-437.

Kvam, Gunn-Turid, Bjørkhaug H. (2014). On healthy growth initiatives in the mid-scale values-based chain of organic food. WP2 of the EU project healthy growth. On line at : orgprints.org.

Lamine, C., Navarrete, M., Cardona, A. (2014). Transitions towards organic farming at the farm and at the local scales: the role of innovative production and organisational modes and networks. In: Stéphane Bellon, Servane Penvern, dir., Organic farming, Prototype for sustainable agricultures. Springer, Dordrecht, pp. 423-438.

Lewis, M., Conaty, P. 2015. Impératif transition. Construire une économie solidaire. Ecosociété (orginal en anglais : 2012).

Litt, J. S., et al. 2011. Connecting food environments and health through the relational nature of aesthetics. Gaining insight through the community gardening experience. Social Science \& Medicine 72 (11): 1853-1863. 
Loorbach, D., Wittmayer, J. M., Shiroyama, H., Fujino, J., \& Mizuguchi, S. (Eds.). (2016). Governance of Urban Sustainability Transitions: European and Asian Experiences. Springer.

Lymbery, Ph. with Oakeshott, I. (2014) Farmageddon. The True Cost of Cheap Meat, Bloomsbury: London, New Delhi, New York, Sydney

Macmillan, R. (2010). The third sector delivering public services: an evidence review.

MacRae, R.; Frick, B.; Martin, R.C. (2007). Economic and social impacts of organic production systems. Can. J. Plant Sci. 87, 1073-1044.

Marsden, T., Smith, E. (2005). Ecological Entrepreneurship: sustainable development in local communities through quality food production and local branding. Geoforum 36: 440-451.

Mathijs, E., Van Hauwermeiren, A., Engelen, G., Coene, H. (2006). Instruments and institutions to develop local food systems. Final Report CP/59, Belgian Science Policy.

Michel A., Hudon M. (2015). Community Currencies and Sustainable Development: A Systematic Review,, Ecological Economics, 116: 160-171.

Nyssens, M. \& Defourny, J. (2016) Fundamentals for an International Typology of Social Enterprise Models (ICSEM Working Papers; 33),

Petrovics, S., Chioncel, N., Karner, S., Salzer, I. (2010). Organic plus - (re)politisation of the food sector? Reflections on two case studies. 9th European IFSA Symposium. Vienna (Austria).

Pinchot, A. (2014). The Economics of Local Food Systems. University of Minnesota.

Polletta, F., \& Jasper, J. M. (2001). Collective identity and social movements. Annual review of Sociology, 283305.

Popa, F., Guillermin, M., \& Dedeurwaerdere, T. (2015). A pragmatist approach to transdisciplinarity in sustainability research: From complex systems theory to reflexive science. Futures, 65, 45-56.

Renagold, J.P. (2012). The fruits of organic farming. Nature.

Rotmans, J., \& Horsten, H. (2012). In het oog van de orkaan: Nederland in transitie. Aeneas.

Ryan, R. and Deci, E. (2000a). Intrinsic and Extrinsic Motivations: Classic Definitions and New Directions. Contemporary Educational Psychology 25: 54-67.

Ryan, R. and Deci, E. (2000b). Self-Determination Theory and the Facilitation of Intrinsic Motivation, Social Development, and Well-Being. American Psychologist 55(1): 68-78.

Schermer, Renting, Oostindie. 2010. Collective Farmers' Marketing Initiatives in Europe: Diversity, contextuality and dynamics. Int. Jrnl. Of Soc. of Agr. \& Food 18(1): 1-11.

Schlicht S., Volz P., Weckenbrock, Ph., Le Gallic Th. (2012). Community supported agriculture: an overview of characteristics, diffusion and political interaction in France, Germany, Belgium and Switzerland (online)

Schot, J., and Geels, F. W. (2008). Strategic niche management and sustainable innovation journeys: theory, findings, research agenda, and policy. Technology Analysis \& Strategic Management, 20(5), 537-554.

Schwartz, E. (2011). A History of CSA. http://www.brooklynbridgecsa.org/articles/a-history-of-csa. (25/05/2011). 
Seufert, V. et al. (2012). Comparing the yields of organic and conventional agriculture. Nature 485:229-232.

Seyfang and Smith (2007). Grassroot innovations for sustainable development: Towards a new research and policy agenda. Environmental politics, 16(4), 584-603.

Seyfang, G., Longhurst, N. (2013). Growing Green Money?: Mapping Community Currencies for Sustainable Development, Ecological Economics, 86, pp.65-77.

Spaargaren, G., Oosterveer, P., Loeber, A. (eds.), 2012. Food Practices in Transition. Changing Food Consumption, Retail and Production in the Age of Reflexive Modernity. New York, London: Routledge.

Spaargaren, gert et al. (2006). Sustainable technologies and everyday life. In: User Behavior and Technology Development (pp. 107-118). Springer Netherlands.

Sunstein, C. (1996), Social Norms and Social Roles. Columbia Law Review. 96: 903

Tissenkopfs, T. Kovach I., Lostak, M., Sumane, S, 2010. Rebuilding and Failing Collectivity: Specific Challenges for Collective Farmers Marketing Initiatives in Post-Socialist Countries. Int. Jrnl. Of Soc. of Agr. \& Food 18(1): 70-88.

United Nations Environment Programme (UNEP) (2011). Visions for Change. Recommendations for Effective Policies on Sustainable Lifestyles.

USDA (2017). Directory of the US Department of Agriculture. On line at https://www.nal.usda.gov/afsic/community-supported-agriculture (accessed 20.01.2017).

Vermeulen S., Campbell B.M., Ingram J.S.I. (2012). Climate Change and Food Systems. Annual Review of Environment and Resources 37(1): 195-222

Virtanen, Y. et al. (2011). Carbon footprint of food - approaches from national input-output statistics and a LCA of a food portion. Journal of Cleaner Production 19: 1849-1856.t.

Willer, H. (2011). The World of Organic Agriculture: Statistics and Emerging Trends (eds Willer, H. \& Kilcher, L.) 26-32 (IFOAM \& FiBL, 2011). 


\section{Annex 1. Definition of the variables and descriptive statistics}

First probit estimation model $(n=104)$

\begin{tabular}{|c|c|c|c|c|c|}
\hline \multicolumn{2}{|l|}{ DEPENDENT VARIABLES } & \multirow{2}{*}{$\begin{array}{l}\text { mean } \\
0.41\end{array}$} & \multirow{2}{*}{$\begin{array}{l}\text { Std. } \\
\text { Dev. } \\
0.49\end{array}$} & \multirow{2}{*}{$\begin{array}{l}\text { Min- } \\
\text { max }\end{array}$} & \multirow{2}{*}{ 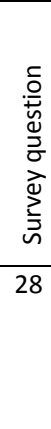 } \\
\hline $\begin{array}{l}\text { Transform Farming } \\
\text { Systems CFBG's } \\
\text { Priority Objective (in } \\
\text { general) }\end{array}$ & $\begin{array}{l}=1 \text { if the following option is ranked first priority for the CFBG's objectives: } \\
\text { Support the farmers that supply the CFBG (local economy, small-scale } \\
\text { farming, sustainable farming practices) } \\
=0 \text { if this option is ranked } 2^{\text {nd }} \text { or } 3^{\text {rd }} \text { (amongst } 3 \text { options) }\end{array}$ & & & & \\
\hline $\begin{array}{l}\text { Sustainable Food } \\
\text { Distribution CFBG' } \\
\text { Priority Objective (in } \\
\text { general) }\end{array}$ & $\begin{array}{l}=1 \text { if the following option is ranked first priority for the CFBG's objectives: } \\
\text { Provide tasty healthy, sustainable and affordable food to the members of the } \\
\text { CFBG (good taste, no pesticides, affordable prices, neglected vegetables) } \\
=0 \text { if this option is ranked } 2^{\text {nd }} \text { or } 3^{\text {rd }} \text { (amongst } 3 \text { options) }\end{array}$ & 0.52 & 0.52 & $0-1$ & 28 \\
\hline \multicolumn{6}{|c|}{ INDEPENDENT VARIABLES (alphabetic order) } \\
\hline $\begin{array}{l}\text { Convivial events } \\
\text { Q26a_10 }\end{array}$ & $\begin{array}{l}=1 \text { if "Meals and Convivial" events are indicated as one of the tools that the } \\
\text { CFBG uses/provides, amongst a list of } 18 \text { proposed tools } \\
=0 \text { if it is not indicated }\end{array}$ & 0.63 & 0.48 & $0-1$ & 26 \\
\hline $\begin{array}{l}\text { Members consulted } \\
\text { for practical advice } \\
\text { q37e_123 }\end{array}$ & $\begin{array}{l}=1 \text { if the option "your organization organizes itself to seek for advices by } \\
\text { requesting its own members" is indicated amongst one of the } 3 \text { most } \\
\text { relevant ways to organise support to the development or improvement of } \\
\text { the food buying group (out of a list of } 5 \text { options) } \\
=0 \text { if it is not selected }\end{array}$ & 0.63 & 0.48 & $0-1$ & 37 \\
\hline $\begin{array}{l}\text { Netw transition towns } \\
\text { qtrall }\end{array}$ & $\begin{array}{l}\text { = } 1 \text { if transition towns are mentioned spontaneously in one of the "open } \\
\text { answers" as an organisation that is trusted/influences beliefs and/or in which } \\
\text { activities they participate } \\
=0 \text { otherwise }\end{array}$ & 0.39 & 0.49 & $0-1$ & $\begin{array}{l}9, \\
19, \\
27 \\
34\end{array}$ \\
\hline Newsletter Q26a_2 & $\begin{array}{l}=1 \text { if "Newsletter" is indicated as one of the tools that the CFBG } \\
\text { uses/provides, amongst a list of } 18 \text { proposed tools } \\
=0 \text { if it is not indicated }\end{array}$ & 0.22 & 0.42 & $0-1$ & 26 \\
\hline $\begin{array}{l}\text { Resources food } \\
\text { transition assoc } \\
\text { q15c6_1 }\end{array}$ & $\begin{array}{l}=1 \text { if buildings (meeting rooms, deposit space, etc.) that are made available } \\
\text { through a sharing arrangements are used from food transition related } \\
\text { associations } \\
=0 \text { if this is not the case }\end{array}$ & 0.06 & 0.03 & $0-1$ & 15 \\
\hline $\begin{array}{l}\text { Resources other assoc } \\
\text { q15a8_b8_c 8 }\end{array}$ & $\begin{array}{l}\text { = } 1 \text { if one of the listed resources (software, list of suppliers, buildings, } \\
\text { common delivery, volunteer time, meals/recipes) are used which are made } \\
\text { available through a sharing arrangement with other associations (not food } \\
\text { related associations: environmental / social) } \\
=0 \text { if this is not the case }\end{array}$ & 0.49 & 0.50 & $0-1$ & 15 \\
\hline $\begin{array}{l}\text { CFBG social } \\
\text { networking q34ab_2 }\end{array}$ & $\begin{array}{l}=1 \text { if the first/second closest Food Buying Group is indicated as being most } \\
\text { influential in shaping beliefs on your own Food Buying Group } \\
=0 \text { if it is not indicated as most influential }\end{array}$ & 0.45 & 0.50 & $0-1$ & 34 \\
\hline \multicolumn{6}{|l|}{ CONTROL } \\
\hline $\begin{array}{l}\text { Reform of the food } \\
\text { system q33_2 }\end{array}$ & $\begin{array}{l}\text { = } 1 \text { if you consider that your own Food Buying Group "struggles against the } \\
\text { food system" } \\
=0 \text { if you consider that your own Food Buying Group "improves the existing } \\
\text { food system" or "builds a different food system" }\end{array}$ & 0.13 & 0.33 & $0-1$ & 33 \\
\hline
\end{tabular}

Second probit estimation model $(n=104)$ 


\begin{tabular}{|c|c|c|c|c|c|}
\hline \multicolumn{2}{|l|}{ DEPENDENT VARIABLES } & \multirow{2}{*}{$\begin{array}{l}\text { mean } \\
0.41\end{array}$} & \multirow{2}{*}{$\begin{array}{l}\text { Std.D } \\
\text { ev. } \\
0.49\end{array}$} & \multirow{2}{*}{$\begin{array}{l}\text { Min } \\
\text { Max } \\
0-1\end{array}$} & \multirow{2}{*}{ 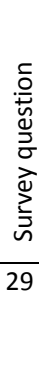 } \\
\hline $\begin{array}{l}\text { Support sustainable farming practices CFBG's } \\
\text { priority objective (in the relation with the farmers) }\end{array}$ & $\begin{array}{l}\text { = } 1 \text { if the following is ranked first priority, as } \\
\text { CFBG's objective concerning support to the } \\
\text { farmers: Support sustainable farming practices }\end{array}$ & & & & \\
\hline $\begin{array}{l}\text { Supporting the local circuits CFBG's priority } \\
\text { objective (in the relation with the farmers) }\end{array}$ & $\begin{array}{l}=1 \text { if the following is ranked first priority, as } \\
\text { CFBG's objective concerning support to the } \\
\text { farmers: Supporting the local circuits } \\
=0 \text { if }\end{array}$ & 0.40 & 0.49 & $0-1$ & 29 \\
\hline \multicolumn{6}{|l|}{ INDEPENDENT VARIABLES (alphabetic order) } \\
\hline Administrative service q37a_12 & $\begin{array}{l}\text { = } 1 \text { if the option "the government organizes a } \\
\text { specific administrative service with } \\
\text { councillors/researchers/advisers" is indicated } \\
\text { amongst one of the } 2 \text { most relevant ways to } \\
\text { organise support to the development or } \\
\text { improvement of the food buying group (out of a } \\
\text { list of } 5 \text { options) } \\
=0 \text { if it is not selected or selected as the } 3^{\text {rd }} \text { most } \\
\text { relevant only }\end{array}$ & 0.28 & 0.46 & $0-1$ & 37 \\
\hline $\begin{array}{l}\text { Members mobilised for functional activities } \\
\text { q22a_1 }\end{array}$ & $\begin{array}{l}=1 \text { if the general organisation tasks (accounting, } \\
\text { invitation for the meetings, organisation of the } \\
\text { collection point, etc.) is distributed amongst the } \\
\text { members (more than } 5 \text { ) } \\
=0 \text { if it is done by a single person or a small } \\
\text { coordinating group (between } 2 \text { and } 5 \text { ) }\end{array}$ & 0.18 & 0.39 & $0-1$ & 22 \\
\hline No CFBG social networking q34b_1 & $\begin{array}{l}\text { = } 1 \text { if the first/second closest Food Buying Group } \\
\text { is indicated as having no influence on shaping } \\
\text { beliefs on your own Food Buying Group } \\
=0 \text { if it is indicated as influential / not applicable }\end{array}$ & 0.31 & 0.46 & $0-1$ & 34 \\
\hline Political legitimacy q36f_4 & $\begin{array}{l}\text { = } 1 \text { if political support (assigning higher priority } \\
\text { to Food Buying Groups within the food system) } \\
\text { is indicated as most importantly needed to } \\
\text { develop or improve activities } \\
=0 \text { if it is indicated as not needed, mildly } \\
\text { needed or needed }\end{array}$ & 0.13 & 0.34 & $0-1$ & 36 \\
\hline Resources food transition assoc q15a6_b6_c 6 & $\begin{array}{l}=1 \text { if one of the listed resources (software, list of } \\
\text { suppliers, buildings, common delivery, volunteer } \\
\text { time, meals/recipes) are used which are made } \\
\text { available through a sharing arrangement with } \\
\text { food related assocations } \\
=0 \text { if this is not the case }\end{array}$ & 0.34 & 0.47 & $0-1$ & 15 \\
\hline Technical support q36c_34 & $\begin{array}{l}\text { = } 1 \text { if technical support (software, logistic } \\
\text { advises, information on new suppliers, } \\
\text { stockroom, tools to improve the inclusiveness or } \\
\text { the efficiency of the Food Buying Group) is } \\
\text { indicated as needed or most importantly needed } \\
\text { to develop or improve activities } \\
=0 \text { if it is indicated as not needed or only mildly } \\
\text { needed }\end{array}$ & 0.36 & 0.48 & $0-1$ & 36 \\
\hline \multicolumn{6}{|l|}{ CONTROL } \\
\hline Building different food system q33_3 & $\begin{array}{l}=1 \text { if you consider that your own Food Buying } \\
\text { Group "builds a different food system" }\end{array}$ & 0.79 & 0.40 & $0-1$ & 33 \\
\hline
\end{tabular}




\begin{tabular}{|l|l|l|l|l|}
\hline & $\begin{array}{l}\text { = } 0 \text { if you consider that your own Food Buying } \\
\text { Group "improves the existing food system" or } \\
\text { "struggles against the food system" }\end{array}$ & & & \\
\hline
\end{tabular}




\section{Annex 2: Correlation matrix amongst the independent variables}

Correlation matrices for the probit estimations on governance features related to resource mobilization and commitment (first model)

\begin{tabular}{|c|c|c|c|c|c|c|c|c|}
\hline & 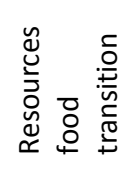 & 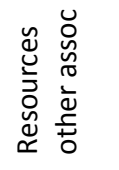 & 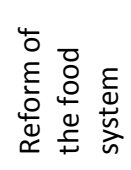 & 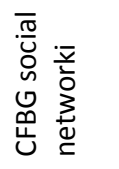 & 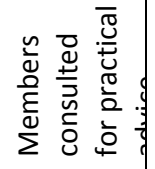 & 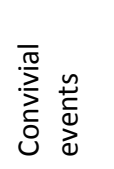 & 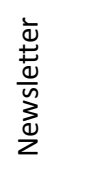 & 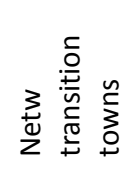 \\
\hline $\begin{array}{l}\text { Resources food } \\
\text { transition assoc }\end{array}$ & 1 & & & & & & & \\
\hline $\begin{array}{l}\text { Resources other } \\
\text { assoc }\end{array}$ & -0.0777 & 1 & & & & & & \\
\hline $\begin{array}{l}\text { Reform of the food } \\
\text { system }\end{array}$ & 0.0312 & 0.0945 & 1 & & & & & \\
\hline $\begin{array}{l}\text { CFBG social } \\
\text { networki }\end{array}$ & -0.0590 & 0.0754 & 0.0657 & 1 & & & & \\
\hline $\begin{array}{l}\text { Members } \\
\text { consulted for } \\
\text { practical advice }\end{array}$ & 0.0934 & 0.1477 & -0.0917 & 0.0109 & 1 & & & \\
\hline Convivial events & 0.1021 & 0.0253 & 0.0453 & -0.1134 & -0.0904 & 1 & & \\
\hline Newsletter & -0.0325 & -0.0593 & -0.0613 & 0.0282 & -0.0993 & -0.0287 & 1 & \\
\hline $\begin{array}{l}\text { Netw transition } \\
\text { towns }\end{array}$ & 0.0587 & 0.2129 & 0.0000 & 0.0764 & 0.0352 & 0.1484 & 0.0073 & 1 \\
\hline
\end{tabular}

Correlation matrices for the probit estimations on governance features related to resource mobilization and policy support (second model)

\begin{tabular}{|c|c|c|c|c|c|c|c|}
\hline & 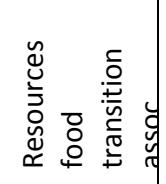 & 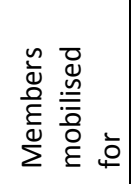 & 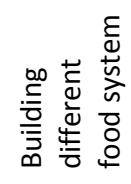 & 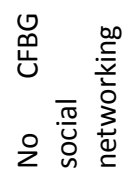 & 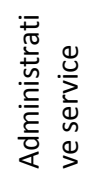 & 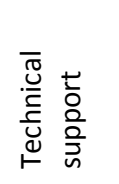 & 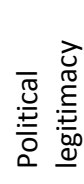 \\
\hline $\begin{array}{l}\text { Resources food transition } \\
\text { assoc }\end{array}$ & 1 & & & & & & \\
\hline $\begin{array}{l}\text { Members mobilised for } \\
\text { functional activities }\end{array}$ & 0.1372 & 1 & & & & & \\
\hline $\begin{array}{l}\text { Building different food } \\
\text { system }\end{array}$ & 0.0894 & 0.0413 & 1 & & & & \\
\hline $\begin{array}{l}\text { No CFBG social } \\
\text { networking }\end{array}$ & -0.0780 & -0.0456 & -0.0447 & 1 & & & \\
\hline Administrative service & -0.1840 & -0.1363 & -0.0663 & 0.0354 & 1 & & \\
\hline Technical support & -0.1467 & 0.0125 & -0.1470 & 0.1138 & 0.1918 & 1 & \\
\hline Political legitimacy & -0.1020 & -0.1136 & 0.0495 & -0.0188 & 0.2463 & -0.0577 & 1 \\
\hline
\end{tabular}

